International Research Journal of Engineering, IT \& Scientific Research
Available online at https://sloap.org/journals/index.php/irjeis/
Vol. 4 No. 5, September 2018, pages: 17 25
ISSN: 2454-2261
https://sloap.org/journals/index.php/irjeis/article/view/287

\title{
Inhibition Activities of Angiotensin Converting Enzyme and Amino Acid Kefir Whey Profile of Skim Milk Fermented by Kefir Grains
}

\author{
Sri Anggreni Lindawati a \\ Gde Mahardika ${ }^{b}$ \\ I Wayan Suardana ${ }^{c}$ \\ Nyoman Semadi Antara ${ }^{d}$
}

\section{Article history:}

Received: 15 May 2018

Accepted: 30 August 2018

Published: 15 September 2018

\section{Keywords:}

Bioactive peptides;

$I C_{50}$;

Inhibition angiotensin converting

enzyme;

Kefir whey;

Products for health;

\begin{abstract}
Bioactive peptides fermented milk is very potential as functional food products for health. The aim of this study is to analyze the inhibition activity of Angiotensin Converting Enzyme and kefir whey amino acid profile and $\mathrm{IC}_{50}$. The design being applied is a comprehensive random design with five treatments (fermentation time $0,3,6,9$ and 12 days) and 3 replications. ACE inhibition indicators include $\mathrm{ACE}$ inhibition with $\mathrm{IC}_{50}$, protein, peptide concentration, total proteolytic, and amino acid profiles. The results show that ACE inhibition activity ranges from $35.94-66.67 \%$ with peptide levels of $872.80-1084.74 \mathrm{mg} / \mathrm{mL}$ and $\mathrm{IC}_{50}$ of $65.48 \mu \mathrm{g} / \mathrm{mL}$, and contained hydrophobic amino acids which functioned for ACE inhibition. The conclusion of this study that the highest ACE inhibition is obtained at 0 day of fermentation with inhibition ability $\left(\mathrm{IC}_{50}\right)$ of $65.48 \mu \mathrm{g} / \mathrm{mL}$ and functioning as nutraceuticals food.
\end{abstract}

2454-2261 ${ }^{\circledR}$ Copyright 2018. The Author. This is an open-access article under the CC BY-SA license (https://creativecommons.org/licenses/by-sa/4.0/) All rights reserved.

\section{Author correspondence:}

Sri Anggreni Lindawati,

Student of Doctorate Program, Program of Animal Science, Udayana University Bali, Indonesia, 80221

Email address: srianggrenilindawati@unud.ac.id

\section{Introduction}

The finding of Angiotensin Converting Enzyme (ACE) inhibition of fermented milk peptides orally is very important in inhibiting hypertension. Inhibition of hypertension, usually using drugs that have side effects, coughing, taste disorders, and skin rashes (Qian et al., 2007). Therefore ACE inhibition can be considered as a useful approach in dealing with blood pressure problems.

a Student of Doctorate Program. Program of Animal Science, Udayana University Bali, Indonesia 80221

${ }^{\mathrm{b}}$ Faculty of Animal Science, Udayana University, Denpasar Bali, Indonesia 80221

${ }^{\mathrm{c}}$ Laboratory of Veterinary Public Health, Faculty of Veterinary Medicine, Udayana University, Denpasar Bali, Indonesia 80221

${ }^{\mathrm{d}}$ Department of Food Science \&Technology, Faculty of Agricultural Technology, Udayana University, Bukit, Jimbaran Bali, Indonesia, 80237 
Angiotensin Converting Enzyme (ACE) is an enzyme that catalyzes the conversion of angiotensin I decapeptide to angiotensin II octapeptide in the Renin-Angiotensin System (RAS) that regulates blood pressure (Riordan, 2003). ACE inhibition is an inhibition of ACE enzymes by bioactive compounds which can reduce blood pressure in humans. This bioactive compound is found in milk. But it has not been able to function optimally as a functional food. Therefore, the potential of functional food is very necessary to improve this functional property, one of which is caused by the help of microorganisms.

Kefir whey is a transparent yellow fermented milk drink, made by fermented milk with kefir seeds, then incubation at 25-27 0C \pm 24 hours (Ot'es and Cagindi, 2003) so that a transparent liquid and separate curd are formed separately. Fanrworth (2005) reported that in kefir grains containing lactic acid bacteria (LAB) and khamir which work in a symbiotic mutualism. Liu et al., (2010) reported that this bacteria is very important in the process of milk fermentation to increase the production of bioactive peptides which have the potential to lower blood pressure through inhibition of Angiotensin Converting Enzyme (ACE inhibitors). The same researcher also reported that the type of bacteria used as a starter will greatly affect the type of peptide produced.

Kefir whey is thought to have the same function as kefir because kefir whey is a liquid, so the components in kefir are dissolved in whey. This condition is in accordance with the explanation of LeBlanc et al. (2004) that bioactive peptides dissolve in water so that they are thought to be components of dissolved protein in the transparent kefir liquid. This is the reason that kefir whey still has high economic value. However, the potential of kefir whey as an ACE inhibitor during storage, little information is obtained, because the ACE inhibitory ability correlates with the number of LAB and metabolites produced. The purpose of this study is to analyze the ability of kefir whey, the highest $\mathrm{ACE}$ inhibitor with $\mathrm{IC}_{50}$ during fermentation. The success of this research is a benchmark for increasing food potential as nutraceuticals food.

\section{Materials and Methods}

\section{Material}

The main materials in this study are 15 liters of fresh cow skim milk and kefir seeds as a starter. The chemicals used in this study, the media Mann Rogosa Shape Agar (MRSA), skim Agar, Pepton Water Buffer (BPW), alcohol, aquades, HCL, and biuret solution. The main equipment in this study are ACE KIT-WST, micro Kjehldal, centrifius, spectrophotometer, microplate reader, incubator, petri dish, refrigerator, autoclave, oven, and pipette.

\section{Metode}

This study applies a Completely Randomized Design (CRD) with five storage treatments (0, 3, 6, 9 and 12 days) with 3 replications (Stell and Torrie, 1993).

\section{Research Procedure}

Preparation of the main tools, such as a petri dish, test tube, pipette, Erlenmeyer, measuring cup is by autoclave sterilizing at $121^{\circ} \mathrm{C} \pm 30$ minutes.

Preparation of the main chemicals, such as MRSA, is by means of weighing 52 grams, then adding $1000 \mathrm{~mL}$ of distilled water and heating it so that it is homogeneous. Furthermore, it was sterilized by autoclaving at a temperature of $121{ }^{0} \mathrm{C} \pm 15$ minutes (Swanson et al., 1993).

The procedure of making Kefir whey follows the Ot'es and Cagindi (2003) method by means of milk being pasteurized to $85^{\circ} \mathrm{C} \pm 30$ minutes then cooled and fermented with kefir grains at a temperature of $25-27^{0} \mathrm{C} \pm 24$ hours. When the kefir is formed, there are two layers: the curd and liquid. Then they are separated so that a transparent yellow liquid is obtained which is called kefir whey. Kefir whey was stored in a refrigerator at $4^{0} \mathrm{C}$ with storage times of $0,3,6,9$ and 12 days.

The variables in this study, ACE kefir whey activity was analyzed by ACE-WST KIT (Nakamura et al., 1995), protein, following the AOAC (2005) method and peptide content with the Biuret method (Brunelli and Waino, 1949), total proteolytic LAB according to the method of Swanson et al., (1993) 


\section{Results and Discussions}

The results showed that the ACE inhibitory activity and the quality of kefir whey fermented for $0,3,6,9$ and 12 days can be seen in Table 1. Amino acid profile of kefir whey with the highest ACE inhibition on 0 days fermentation in Table 2

Table 1

Inhibition Activity of ACE and the quality of kefir whey skim milk which is fermented by kefir seed during its storage

\begin{tabular}{lccccc}
\hline \multirow{2}{*}{ Variable } & \multicolumn{5}{c}{ Treatment (day) } \\
\cline { 2 - 5 } & 0 & 3 & 6 & 9 & 12 \\
\hline Inhibition & $66.67^{\mathrm{a}}$ & $54.84^{\mathrm{b}}$ & $35.49^{\mathrm{c}}$ & $39.79^{\mathrm{c}}$ & $38.79^{\mathrm{c}}$ \\
ACE $(\%)$ & & & & \\
Protein $(\%)$ & $1.58^{\mathrm{b}}$ & $1.52^{\mathrm{b}}$ & $1.37^{\mathrm{a}}$ & $1.39^{\mathrm{a}}$ & $1.37^{\mathrm{a}}$ \\
$\begin{array}{l}\text { Total BAL } \\
\text { Proteolytic } \\
(\mathrm{cfu} / \mathrm{mL})\end{array}$ & $4.4 \times 10^{3 \mathrm{a}}$ & $3.1 \times 10^{3} \mathrm{a}$ & $5.5 \times 10^{3 \mathrm{a}}$ & $7.2 \times 10^{3 \mathrm{a}}$ & $2.0 \times 10^{1 \mathrm{~b}}$ \\
$\begin{array}{l}\text { Peptide } \\
(\mu \mathrm{g} / \mathrm{mL})\end{array}$ & & & & \\
& & & & \\
& $1084.74^{\mathrm{a}}$ & $995.11^{\mathrm{b}}$ & $872.88^{\mathrm{c}}$ & $1066.95^{\mathrm{a}}$ & $869.18^{\mathrm{c}}$ \\
\hline Description: different superscripts on the same line show a significant difference $(\mathrm{P}<0.05)$
\end{tabular}

\subsection{ACE Inhibition}

ACE inhibition is an inhibition of the ACE enzyme that causes hypertension by blocking the change of angiotensin I to angiotensin II, which is a strong vasoconstrictor that causes hypertension (Liu et al., 2010, Korhonen and Pihlanto 2006).

Fermentation duration of 0, 3 and 6 days $(\mathrm{P}<0.05)$ decreased ACE kefir whey inhibitory activity. However, 6 12 days of fermentation were no a significant difference $(\mathrm{P}>0.05)$. The highest ACE inhibition is obtained on 0 fermentation days with IC50 is $65.49 \mu \mathrm{g} / \mathrm{mL}$. The high ACE inhibition is due to the activity of Lactobacillus and Leuconostoc which a proteolytic LAB, hydrolyzing proteins into oligopeptides, peptides during fermentation (Fanrworth, 2005). This occurs at the beginning of fermentation because LAB is in a position on the surface of kefir seeds, while khamir is on the inside (Graciela et al., 2010) and peptides formed at 0 days are thought to be metabolites that have a function as ACE inhibitors. These results are similar to those reported by Febrisiantosa et al, (2013) that ACE inhibition correlates with the number of peptides. However, ACE inhibition on fermentation duration of 6 - 12 days was lower ( $>>0.05$ ), although it was followed by an increase in the number of the proteolytic labs at 9 days. When viewed from the peptide concentration, there was an increase in 9 days, i.e. $1066.95 \mathrm{mg} / \mathrm{mL}$ but ACE inhibition was low, then at 12 days, there was a decrease (Table 1). Low ACE inhibition, presumably produced metabolites, only partly as a peptide that functions as a hypertensive inhibitor, because Korhonen and Pihlanto (2006) reported that peptides have different functions, namely as antihypertensive, opioid, antimicrobial and immune systems. Miller et al., (2007) reported that whey still has bioactive components, especially from whey protein. Ebringer et al. (2008), a source of peptides from whey, namely $\beta$-lactoglobulin and $\alpha$-lactalbumin have functioned as a source of antihypertensive peptides. ACE inhibition in this study is different from that produced by Febrisiantosa et al, (2013) that is equal to $73.07 \%$ with raw ingredients of fermented whey cheese with kefir grains

The mechanism of ACE inhibition by peptide whey kefir as an inhibitor, due to the peptide produced by LAB, will inhibit the ACE enzyme as a precursor that converts Angiotensin I to II Angiotension, which is a strong constructor that triggers aldosterone synthesis and release, which causes increased blood pressure, narrowing of blood vessels (Liu et al, 2010). ACE enzyme inhibition by inhibitory peptides is initiated by the binding of ACEinhibiting peptides to the three active sides of the ACE enzyme. Wijesekara and Kim (2010) this binding peptide changes the composition of the protein so that there is no interaction between angiotensin I and the active side of the ACE enzyme. It was also reported that by binding to the peptides on the three active sides of the ACE enzyme,

Lindawati, S. A., Mahardika, G., Suardana, I. W., \& Antara, N. S. (2018). Inhibition activities of angiotensin converting enzyme and amino acid kefir whey profile of skim milk fermented by kefir grains. International Research Journal of Engineering, IT \& Scientific Research, 4(5), 17-25. https://doi.org/10.21744/irjeis.v4n5.287 
namely C-terminal, plays an important role in ACE inhibitors, which binds to hydrophobic amino acids. Nakamura et al. (1995), Korhonen and Pihlanto (2006) report that the functional properties of ACE inhibitors are largely determined by the amino acid composition of bioactive peptides derived from milk protein namely Val-Pro-Pro or Ileu-Pro-Pro. However, the amino acid sequence in the C-terminal is only a control of the inhibiting peptide, because this sequence is still learned. Besides that, Madureira et al. (2010) stated the type of BAL used as a starter will determine the type of peptide.

\subsection{Protein level}

The highest protein levels were found in the fermentation period of 0 days which was $1.58 \%$ and the lowest was at 12 days, which was $1.37 \%$. The low protein content in all treatments was caused, the sample used in this study was kefir whey, in the form of transparat liquid, the result of separation with curd kefir (Figure 2.) so that part of the biomass was still bound to the kefir grain matrix or polysaccharide (Graciela et al., 2010). However, LeBlanc et al., (2004) reported that kefir granules

However, LeBlanc et al., (2004) reported were diss dissolved in water, so that in kefir whey still contain kefir protein content in curd kefir consumption was consumption during storage up to 12 days was $4.74-4.08 \%$. Compared to SNI, it was still in standard. BSN-SNI (2009) that the minimum limit of kefir protein is $1 \%$.

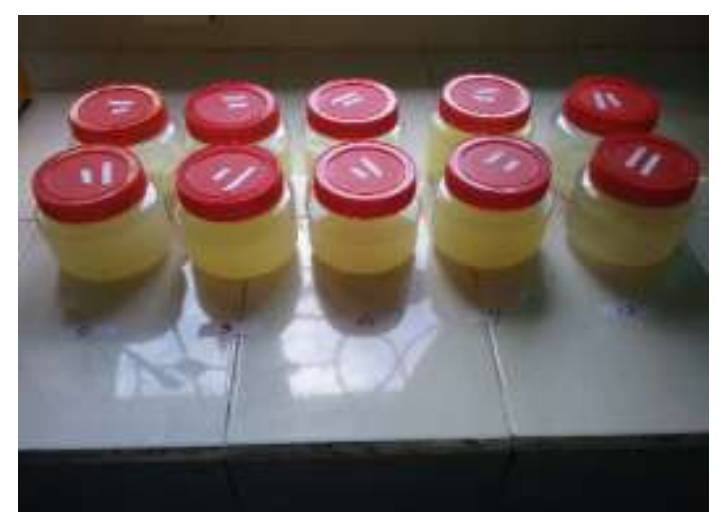

Figure 1. Kefir Whey

In the process of fermentation of milk by kefir grains, Fanworth (2005) reported that the activity of LAB (Lactobacillus and Leuconostoc), begins with the degradation of lactose into lactic acid. Lactic acid is formed, coagulating proteins so that curd occurs. Then this bacterium with its proteolytic enzyme (intracellular peptidase enzyme) hydrolyzes proteins into oligopeptides, tri-di peptides, and amino acids. Pihlanto et al., (2000) reported that the results of this hydrolysis were first used as nutrients by the LAB and the remaining potential as a functional food for health. This situation stimulates Streptococcus growth. The presence of Streptococcus, causes the atmosphere to become acidic and can inhibit its growth. However, it actually stimulates Lactobacillus to regrow so that the total proteolytic LAB is currently low.

The high levels of this protein are also caused by the total proteolytic BAL that forms a clear zone in its growth in petri dishes (Figure 2). This indicates a higher level of protein biodegradation (Table 1), thus causing an increase in biomass from metabolic LAB results. Acidity, a decrease in protein levels was followed by a total proteolytic BAL, although it was not statistically significant $(\mathrm{P}<0.05)$, because Farnworth (2005), states that bioactive component in kefir is kefir seed microbes, its metabolites (polysaccharides, peptides) which have potential health. 


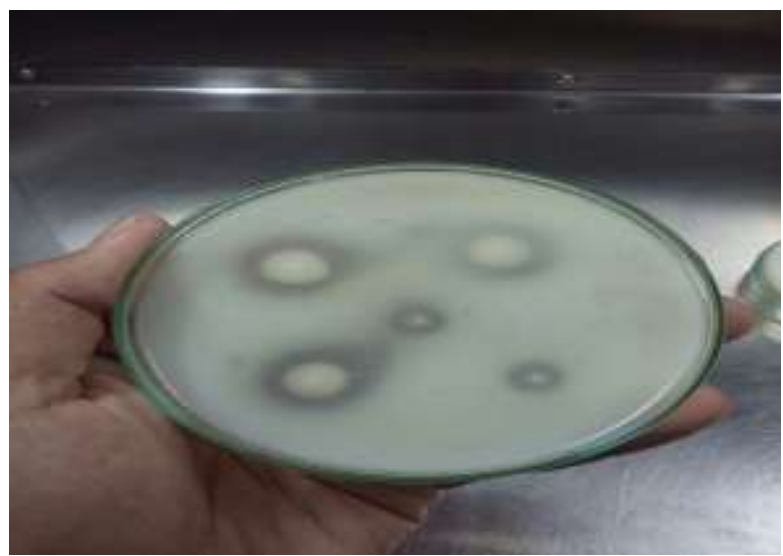

Figure 2. Zona of LAB proteolitik on skim agar

\subsection{Total BAL Proteolytic}

The results of variance showed that the amount of proteolytic LAB with fermentation duration of 0 - 9 days was not significant $(\mathrm{P}>0.05)$, but in the 12 th fermentation was significantly $(\mathrm{P}<0.05)$ decreased. This indicates that the fermentation duration of 0 - 9 days has not shown an increase in the number of proteolytic bacteria, assumed to enter the stationary phase. Mainvifle (2006) reported that in the stationary phase there was a decrease in the number of Streptococcus, due to the acid produced (the higher the fermentation time, 2.52 - 3.77), but Lactobacillus growth occurred. While Lund and Eklund (2000) reported that LAB grew optimally at pH 4.82 - 4.39. However, there was a decrease in the amount of proteolytic BAL in the 12-day fermentation period, due to the growth of molds.

\subsection{Kadar Peptide}

The level of kefir whey peptide is the result of biodegradation of BAL, an especially proteolytic group so that all processes during fermentation are affected by its activity and nutrient content in the product. Peptides obtained in this study were significant $(\mathrm{P}<0.05)$ influenced by fermentation time (Table 1$)$. The high levels of peptide were found in the fermentation period 0 day. This is due to the process of fermentation of milk by proteolytic lactic acid bacteria causing an acidic atmosphere. Acidic conditions besides causing coagulation of proteins, further hydrolysis of proteins occurs by proteolytic enzymes to oligopeptide and peptide.

In the fermentation period of 3 - 9 days there was a decrease in peptide levels, due to a decrease in proteolytic lactic acid bacteria (Streptococcus), while at day 9 there was an increase in peptide levels $(\mathrm{P}<0.05)$. It is caused by the increase of Lactobacillus (Farnworth, 2005). Meanwhile on the 12 days, the decrease of peptide level occurs, because it is dominated by the growth of molds. Nurhayati et al., (2013) stated that the acidity causes a positive ion exchange with negative ions in the acid, so that the breakdown of the protein structure results in the breakdown of the peptide bond chain into peptides with shorter chain amino acids.

\subsection{Amino Kefir Whey Acid Profile}

The amino acid profile shown is the amino acid from whey kefir with the highest ACE inhibition on 0 days of fermentation and also displayed 3 days of fermentation time and milk can be seen in Table 2.

Lindawati, S. A., Mahardika, G., Suardana, I. W., \& Antara, N. S. (2018). Inhibition activities of angiotensin converting enzyme and amino acid kefir whey profile of skim milk fermented by kefir grains. International Research Journal of Engineering, IT \& Scientific Research, 4(5), 17-25. https://doi.org/10.21744/irjeis.v4n5.287 
Table 2

Profile of Amino Acid Milk, Kefir Whey with Fermentation Length

0 and 3 days

\begin{tabular}{lccc}
\hline \multicolumn{1}{c}{ Amino Acid } & Milk & Whey 0 day & Whey 3 days \\
\hline Serine & 1607.22 & - & $<830.17$ \\
Glutamic acid & 6559.33 & 834.75 & 702.92 \\
Phenylalanine & 1486.66 & 191.57 & 173.60 \\
Isoleucine & 1537.70 & 223.80 & 208.65 \\
Valine & 1723.38 & 222.74 & 203.83 \\
Alanine & 1026.18 & 373.33 & 369.55 \\
Arginine & 907.54 & $<153.15$ & $<153.15$ \\
Glysine & 618.36 & $<402.00$ & $<402.00$ \\
Lysine & 2909.85 & 393.11 & 359.22 \\
Aspartate acid & 2220.37 & $<399.37$ & $<399.37$ \\
Leucine & 2894.32 & 381.18 & 339.39 \\
Tyrosin & 1242.26 & $<222.88$ & $<222.88$ \\
Proline & 2616.84 & 352.30 & 274.68 \\
Threonine & 1385.21 & 294.74 & 250.63 \\
Histidine & 736.58 & $<136.06$ & $<136.06$ \\
Metionine & 712.70 & 87.17 & 61.02 \\
Sistine & 161.24 & - & - \\
Tryptopan & 258.56 & $<56.14$ & $<56.14$ \\
\hline
\end{tabular}

The results of analysis of the content of amino acid kefir whey with fermentation time of 0,3 days and milk, with HPLC, consists of hydrophobic amino acids (Isoleucine, Alanine, Leucine, Proline, Valine, Glycine) and hydrophilic (Serine, Glutamic Acid, Aspartate Acid, Threonine, Methionine,). However, it differs in the ability to inhibit ACE. This difference is thought to be caused by the short and length of the peptide chain. Wikandari and Yuanita (2014) reported that peptides have the potential as antihypertensive agents are short-chain with 2 - 12 amino acid residues and are strongly influenced by fermentation duration. The content of amino acids is very closely related to ACE inhibition. Qian et al., (2007), reported that ACE inhibition occurs, if there is a hydrophobic amino acid peptide inhibiting bond with three active ACE enzymes in C-terminal. Meanwhile, the hydrophilic amino acid, which has ACE inhibition, is very weak because it is not compatible with the active side of the ACE enzyme. Abubakar (2014) reported the results of his research that ACE inhibition occurs if there are several proline amino acid residues in the peptide chain)

\section{Conclusion}

The conclusion of this study that:

a) Inhibition activity of Angiotensin Converting Enzyme kefir whey is obtained on 0 fermentation days with $\mathrm{IC}_{50}$ is $65.48 \mu \mathrm{g} / \mathrm{mL}$

b) Profile of amino acids that function to inhibit ACE including hydrophobic

c) Amino acids with peptide levels $1084.74 \mathrm{mg} / \mathrm{mL}$.

d) Kefir whey functions as nutraceuticals food.

Conflict of interest statement and funding sources

The authors declared that they have no competing interest. The study was financed by personal funding.

Statement of authorship

The authors have a responsibility for the conception and design of the study. The authors have approved the final article. 
Acknowledgments

My gratitude's goes to the Rector of Udayana University to give the chance to study at the Doctorate Program at

Faculty of Animal Science at Udayana University and to the Supervisor and Co-Supervisors for their supervision during the research.

Lindawati, S. A., Mahardika, G., Suardana, I. W., \& Antara, N. S. (2018). Inhibition activities of angiotensin converting enzyme and amino acid kefir whey profile of skim milk fermented by kefir grains. International Research Journal of Engineering, IT \& Scientific Research, 4(5), 17-25. https://doi.org/10.21744/irjeis.v4n5.287 


\section{References}

Abubakar. (2004). Isolasi peptida antihipertensi dari protein susu. J. Indon. Trop. Anim. Agric. 29(3): 121-128

AOAC, Cunniff, P. (1996). Official methods of analysis of AOAC International (No. Sirsi) i9780935584547). Association of Official Analytical Chemists.

Brunelli, E., \& Wainio, W. W. (1949). A further purification of d-glucose dehydrogenase. Journal of Biological Chemistry, 177(1), 75-79.

Ebringer, L., Ferenčík, M., \& Krajčovič, J. (2008). Beneficial health effects of milk and fermented dairy products. Folia Microbiologica, 53(5), 378-394.

Farnworth, E. R. (2006). Kefir-a complex probiotic. Food Science and Technology Bulletin: Fu, 2(1), 1-17.

Febrisiantosa, A., Purwanto, B. P., Widyastuti, Y., \& Arief, I. I. (2013). Karakteristik Fisik, Kimia, Mikrobiologi Whey Kefir Dan Aktivitasnya Terhadap Penghambatan Angiotensin Converting Enzyme (ACE)[Physical, Chemical and Microbiological Characteristics of Whey Kefir and Its Angiotensin Converting Enzyme (ACE) Inhibitory Act. Jurnal Teknologi dan Industri Pangan, 24(2), 147.

Garrote, G. L., Abraham, A. G., \& De Antoni, G. L. (2010). Microbial Interactions in Kefir: A Natural Probiotic Drink. Biotechnology of Lactic Acid Bacteria: Novel Applications, 327.

Jarvis, J. K., McBean, L. D., \& Miller, G. D. (2002). Handbook of dairy foods and nutrition. CRC press.

Korhonen, H., \& Pihlanto, A. (2006). Bioactive peptides: production and functionality. International dairy journal, 16(9), 945-960.

LeBlanc, J., Fliss, I., \& Matar, C. (2004). Induction of a humoral immune response following an Escherichia coli O157: H7 infection with an immunomodulatory peptidic fraction derived from Lactobacillus helveticusfermented milk. Clinical and diagnostic laboratory immunology, 11(6), 1171-1181.

Liu, J., Yu, Z., Zhao, W., Lin, S., Wang, E., Zhang, Y., ... \& Chen, F. (2010). Isolation and identification of angiotensin-converting enzyme inhibitory peptides from egg white protein hydrolysates. Food chemistry, 122(4), 1159-1163.

Madureira, A. R., Tavares, T., Gomes, A. M. P., Pintado, M. E., \& Malcata, F. X. (2010). Invited review: physiological properties of bioactive peptides obtained from whey proteins. Journal of dairy science, 93(2), 437455.

Mainville, I., Robert, N., Lee, B., \& Farnworth, E. R. (2006). Polyphasic characterization of the lactic acid bacteria in kefir. Systematic and applied microbiology, 29(1), 59-68.

Nakamura, Y., Yamamoto, N., Sakai, K., Okubo, A., Yamazaki, S., \& Takano, T. (1995). Purification and characterization of angiotensin I-converting enzyme inhibitors from sour milk. Journal of dairy science, 78(4), 777-783.

Nasional, B. S. (1992). Yoghurt. SNI-01-2981-1992. Jakarta: Badan Standardisasi Nasional Indonesia.

Nurhayati, N., Tazwir, T., \& Murniyati, M. (2013). Ekstraksi dan Karakterisasi Kolagen Larut Asam dari Kulit Ikan Nila (Oreochromis niloticus). Jurnal Pascapanen dan Bioteknologi Kelautan dan Perikanan, 8(1), 84-92.

Otles, S., \& Cagindi, O. (2003). Kefir: a probiotic dairy-composition, nutritional and therapeutic aspects. Pakistan Journal of Nutrition, 2(2), 54-59.

Pihlanto-Leppälä, A. (2000). Bioactive peptides derived from bovine whey proteins: opioid and ace-inhibitory peptides. Trends in food science \& technology, 11(9-10), 347-356.

Qian, Z. J., Jung, W. K., Lee, S. H., Byun, H. G., \& Kim, S. K. (2007). Antihypertensive effect of an angiotensin Iconverting enzyme inhibitory peptide from bullfrog (Rana catesbeiana Shaw) muscle protein in spontaneously hypertensive rats. Process Biochemistry, 42(10), 1443-1448.

Riordan, J. F. (2003). Angiotensin-I-converting enzyme and its relatives. Genome biology, 4(8), 225.

Steel, R. G., \& Torrie, J. H. (1993). Prinsip dan prosedur statistik suatu pendekatan biometrik. Principles and Procedures of Statistics, terjemahan Ir, Bambang Sumantri) Cetakan ke-3, PT. Gramedia, Jakarta.

Swanson, K. M. J., Busta, F. F., Peterson, E. H., \& Johnson, M. G. (1992). Colony count methods. Compendium of methods for the microbiological examination of foods, 3, 75-95.

Wijesekara, I., \& Kim, S. K. (2010). Angiotensin-I-converting enzyme (ACE) inhibitors from marine resources: prospects in the pharmaceutical industry. Marine drugs, 8(4), 1080-1093.

Wikandari, P. R., \& Yuanita, L. (2014). Potensi bekasam yang difermentasi dengan Lactobacillus plantarum B1765 dalam menurunkan tekanan darah tikus hipertensi. In Prosiding Seminar Nasional Kimia, Program Studi Kimia, Fakultas MIPA. 


\section{Biography of Authors}

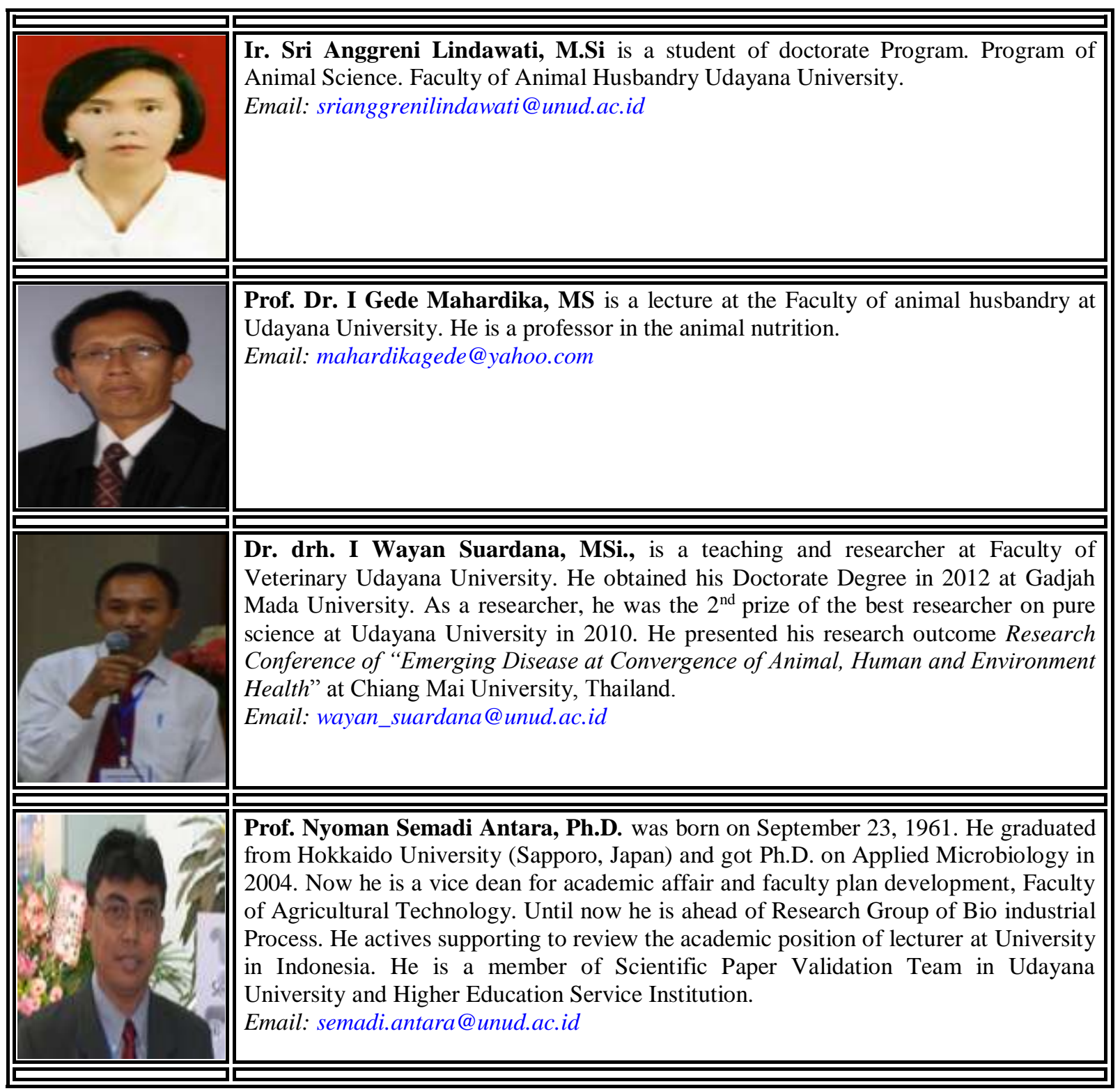

Lindawati, S. A., Mahardika, G., Suardana, I. W., \& Antara, N. S. (2018). Inhibition activities of angiotensin converting enzyme and amino acid kefir whey profile of skim milk fermented by kefir grains. International Research Journal of Engineering, IT \& Scientific Research, 4(5), 17-25. https://doi.org/10.21744/irjeis.v4n5.287 